\title{
The Surrender of Tobruk in 1942: Press reports and soldiers' memories
}

\author{
Karen Horn and David Katz ${ }^{\bullet}$
}

\begin{abstract}
Most quarters of the Allied camp greeted the fall of Tobruk on 21 June 1942 with incredulity. The epitome of a heroic defence conducted the year before had now deteriorated into a military debacle, resulting in thousands of Allied soldiers sent 'into the bag'. The enormity of the defeat, at first greeted in muted fashion by a stunned press, soon turned into outrage at yet another Allied military fiasco. The British and South African papers began to demand answers from politicians and military leaders for this shocking and unexpected catastrophe. The press, normally sensitive to maintaining positive home front morale, discarded their wartime cosseting approach and embarked on a quest to find a scapegoat. Those captured at Tobruk were equally outraged that their freedom had been traded cheaply with hardly a fight. To many of these prisoners of war, the blame for their ignominious surrender rested squarely with the fortress commander, Major General HB Klopper. It was of little consequence to those now languishing behind the wire that the reasons for defeat were much more intricate and went beyond the performance of one man. This article examines a selection of representative press reports in the weeks immediately preceding and following the rout, and the oral reminiscences of former prisoners-of-war taken at Tobruk, which together, have contributed towards an enduring memory of the so-called Tobruk 'debacle'. ${ }^{1}$
\end{abstract}

Keywords: Prisoners of war (POWs), World War II, Union Defence Force, Erwin Rommel, Auchinleck, Ritchie, HB Klopper, South Africa, Eighth Army, Gazala

\section{Introduction}

The fall of Tobruk occurred almost to the day on the 30-year anniversary of the formation of the Union Defence Force (UDF) on 1 July 1912, and constituted the single biggest defeat in its brief history. Almost the entire $2^{\text {nd }}$ South African Infantry (SAI) Division marched into captivity on 21 June 1942 when Major General HB Klopper surrendered to Lt Gen. Erwin Rommel and his Afrika Korps (DAK). As a result, a huge stockpile of munitions and transport vehicles together with approximately 33000 Allied soldiers, of which 12000 belonged to the UDF, fell into Rommel's hands. ${ }^{2}$ This immense haul in booty was much needed grist to the mill of a depleted DAK who used this considerable captured supply to add impetus to their pursuit of the fleeing Eighth Army.

Rommel was able to surround and lay siege to Tobruk for a second time due to the British having suffered a major defeat in the Battles of the Cauldron in the preceding weeks. ${ }^{3}$ The Axis offensive began on 26 May 1942 at 14:00 with an Italian diversionary attack in the north of the Gazala line. At 22:30, in a daring night move, the main Axis forces launched their attack by choosing to take

Karen Horn is a lecturer in the Department of Curriculum Studies at the Faculty of Education at Stellenbosch University. Email: karenhorn@sun.ac.za.

Major DB (David) Katz completed his MMil in the Department of Military History, Stellenbosch University and is a doctoral candidate in the Department of Military History, Stellenbosch University. Email: dkatz@sun.ac.za. 
the indirect approach via a flanking movement around Bir Hacheim. Tobruk's capture was optimistically targeted for the third day of the offensive. As the fortified port was the most important target for the Axis offensive, Rommel's advance behind the Gazala line directly threatened Tobruk. In the weeks that followed, the fortunes of war swayed first one way and then the other until the Germans were eventually able to defeat the British armour decisively and drive all the British forces back to the Egyptian frontier. Libya was now effectively devoid of British troops. The only Allies remaining in Libya were the South African $1^{\text {st }}$ division under Klopper, effectively abandoned in an isolated Tobruk. ${ }^{4}$

The decision to defend Tobruk, despite the sound beating delivered by Rommel on the Eighth Army in the Cauldron, was not without controversy. It was made contrary to an earlier decision by Gen. Sir Claude Auchinleck, Commander-in-Chief Middle East, that should the defence of the forward positions in the Gazala line become untenable, Tobruk was to be abandoned. ${ }^{5}$ However, at the eleventh hour, Auchinleck intervened as he perceived the circumstances were different from what he originally envisaged. He felt that the Eighth Army was far from being beaten and that the infantry divisions were largely intact. Auchinleck reasoned, "The Eighth Army was ... still strong enough to provide an adequate garrison for Tobruk and to maintain a mobile field force to the east and south capable of preventing the fortress being permanently besieged." Simultaneously, furthering the state of confusion, Churchill sought assurance that Tobruk was not to be abandoned. ${ }^{7}$ Gen. Neil Ritchie, commander of the Eighth Army, was intent on withdrawing to the Egyptian frontier whether Tobruk was to be held in isolation or abandoned. However, when corresponding with Auchinleck, Ritchie's intentions were couched in less definite terms and he spoke of the possibility of Tobruk being cut off for a time. ${ }^{8}$ Due to a crisis in command and control and miscommunication between Auchinleck and Ritchie, Tobruk was isolated and surrounded by Rommel on 18 June 1942.

The Gazala battles, culminating in the fall of Tobruk, have been the subject of many official, campaign and regimental histories produced by nearly all the participating nations. ${ }^{9}$ However, the POW experience has not been as widely attended to as other popular aspects of the Second World War. Similarly, the Fall of Tobruk in 1942 has receded from South Africa's collective memory to the extent that it has become part of the national amnesia. The historiographic focus has shifted from Afrikaner nationalism to Struggle history, both of which have neglected the country's participation in World War II. ${ }^{10}$

Regarding the POW experience, international scholars such as Bob Moore and Kent Fedorowich, Barbara Hately-Broad, Arieh J Kochavi, Simon Mackenzie and Adrian Gilbert have made significant forays into the topic. However, most of these writers used a thematic approach by examining the treatment of prisoners by their captors and aspects of the POWs' daily life, including camp entertainment and recreation. ${ }^{11}$ Using this approach has somewhat obscured, or not attended to, the unique views of the different nationalities that made up the Allied forces. In many ways, the surrender of Tobruk was a particularly South African experience. Taken together with South Africa's divisive political background and racist milieu would have given South African POWs an incomparable perspective and war experience. ${ }^{12}$

This article departs from conventional military analysis and examines the fall of Tobruk in June 1942 through the lens of the media who reported it and the reminiscences of the POWs who experienced the event first-hand. The POW perspective taken together with press reports of the day, offers a unique insight into the surrender of Tobruk. Shifts in reporting by an increasingly critical media together with the swings in POW perception are traced in the days before, during and after the surrender of Tobruk. 


\section{The press, government and the protection of home front morale}

The events leading to the fall of Tobruk, including Klopper's dismal performance, are immersed in controversy that persists among military historians to this day. Adding to the general fog of war was the historically fragile relationship between South Africa and the United Kingdom. Both countries were particularly sensitive to the negative effect that the military losses at Tobruk would have on their respective home fronts and delicate relations. These issues added to the ensuing debacle that played out in the press and among the politicians of the day.

Smuts had gone out on a political limb to bring South Africa into the war, a decision that was extremely unpopular amongst certain sectors of the Afrikaner community. The surrender of Tobruk followed on the heels of the destruction of the $5^{\text {th }}$ South African Infantry Brigade at Sidi Rezegh on 23 November 1941. Before Tobruk, the loss of an entire brigade dwarfed even the disaster at Delville Wood in World War I. Such huge losses were bound to cause dissention back on the home front. The government needed to mitigate the effect of bad news on a divided population. Smuts was acutely aware of the negative repercussions that would feed the anti-war posture amongst nationalist circles. An example of this was Carel Birkby's early release of an account on the battle of Sidi Rezegh. Birkby managed to evade the censors, much to the chagrin of Smuts. Shortly before its publication, Smuts had released a version of the battle, which minimised the magnitude of the losses suffered. ${ }^{13}$

In a similar vein, home front morale was of great concern to the British government. A series of strategic Allied defeats sapped the morale of its citizens. In 1940, the evacuation at Dunkirk caused 30000 Allied casualties, and two years later, the fall of Singapore resulted in the surrender of approximately 85000 Allied soldiers. ${ }^{14}$ Although Dunkirk was seen as a victory of sorts by the British, the high number of casualties suffered there, and also during the Blitz and the Battle of Britain, could not be ignored..$^{15}$ The 'total' nature of the conflict ensured that the war directly affected civilians, and thus morale became very important in what became known as the "people's war". ${ }^{16}$ The press became an essential tool in keeping morale high, and a propaganda campaign prevented any reports that may have been perceived as creating panic or pessimism in the public domain. ${ }^{17}$

The British government was not beyond taking action in order to maintain a positive outlook among its citizens. In comparison to Smuts' mere irritation at Birkby's circumventing of censorship regarding Sidi Rezegh, the British government shut down the Daily Worker and issued a warning to the Daily Mirror when articles in these two newspapers were believed to have a negative effect on home front morale. ${ }^{18}$ Motivation for controlling news from the frontline also derived from a sound military intelligence need to prevent the enemy from gaining information. For instance, news of the Battle for the Atlantic hardly ever reached the British public as strict censorship was applied to prevent Germany gaining access to information on this front. ${ }^{19}$ Beside the onerous burden of censorship, the British press was somewhat confined by a patriotic duty to enhance home front morale and protect inter-Allied relations when reporting the events.

South Africa differed from the United Kingdom in the extent of the division in its population over the war effort. To a large extent, the anti-British feeling amongst the Afrikaans-speaking section of the population was reflected in Afrikaans newspapers, while English newspapers adopted a proBritish line and supported the war effort, in line with the opinion of their readers. Despite differing political viewpoints, most newspapers in the Union received their news from the South African Press Association (SAPA). This was a result of an agreement in 1938 stipulating that Reuters would provide all news to SAPA. Because of sharing a common information conduit, the articles in both the Afrikaans and English press tended to be similar and for the same reasons differed little from those reported by British newspapers. ${ }^{20}$ In Britain, besides relying on Reuters for war news, the Daily Mail and The Times used their own correspondents who reported from Egypt. The Times was especially purposeful with 
regard to its own correspondents, as it wanted to maintain its individuality amongst the many newspapers that looked to Reuters for war reports. ${ }^{21}$

Afrikaans papers such as Die Burger, Die Transvaler and Die Vaderland faced a dilemma due to receiving their news via SAPA, as they perceived that these reports were sympathetic to the Allied cause. In many cases, newspapers made their opinions heard by placing their anti-war articles on page four. Their views were often opposed to and even antagonistic towards the war and the Union's participation. Another technique used by the Afrikaans press to counteract the pro-war views of the Reuters and SAPA reports, was to place the news from the German communiqués first. The prominence of the German reports created the impression amongst readers that the Axis point of view was of greater importance. In contrast, English papers relegated German communiqués to the last paragraphs of SAPA Reuters' articles.

The Tobruk debacle was shrouded in a veil of secrecy and the findings of the Tobruk Court of Enquiry remained undisclosed and out of the public realm for decades after the event. ${ }^{22}$ However, the press, confronted with a long series of Allied military setbacks, reflected the frustration of their readers who demanded answers in the face of perceived military ineptitude. In a final irony, the defeat suffered at Tobruk was within a few months surpassed by major Allied victories at Alamein in November 1942 and Stalingrad in January 1943. The humiliation of Tobruk was soon forgotten, and the press busied itself with happier and more newsworthy items as 1943 brought in a string of unmitigated Allied victories. $^{23}$

\section{Background and events leading to the surrender of Tobruk, 21 June 1942}

On 15 May 1942, a newly promoted Klopper took over command of the $2^{\text {nd }}$ SAI Division from Major General IP de Villiers, then eleven years Klopper's senior. De Villiers, in stark contrast to Klopper, had seen extensive service in World War I, South West Africa and France. Klopper experienced a somewhat meteoric rise to become a divisional commander some fifteen years after his attestation, becoming a general before his fortieth birthday. ${ }^{24}$ Unfortunately, this was his first combat command, never having commanded a regiment or a brigade in the heat of war and being too young to have seen any First World War service. ${ }^{25}$ The division that Klopper commanded was similarly without much battle experience. It had seen little action since it left South Africa on 20 April 1941. During the Crusader Operation, $2^{\text {nd }}$ SAI Division was held in reserve due to a lack of transport. The command structures of $2^{\text {nd }}$ Division were filled with newly promoted officers, the more seasoned ones having departed with De Villiers, creating what must have been an unsettling situation..$^{26}$ The $2^{\text {nd }}$ Division under Klopper now found itself in the unenviable position of having to defend Tobruk against the victorious and rampant Rommel. We therefore have a picture of a very young, inexperienced commander, assisted by an inexperienced staff and commanding a division that had seen very little action.

In contrast, the press chose to present a particularly confident tone when the North African desert erupted once more after months of stalemate in which both sides took the opportunity to rebuild their forces. The Times war correspondent reported on 28 May 1942 that the "lull on the Libyan front has broken" 27 when Rommel's army began to move. The correspondent added, "General Ritchie's Eighth Army is composed of British, Indian, South African, and Free French troops, fighting fit and in the highest spirits." ${ }^{28}$ To strengthen his point, The Times correspondent added that the Eighth Army troops had been subjected to "intensive training" during the lull and that the Army had learned lessons from previous battles in the desert, specifically regarding the "securing of coordination of all arms and the use of tanks in masses". ${ }^{29}$ 
A few days after The Times article appeared, Die Burger, through SAPA, reported along similar lines and stated that, although Rommel may have had access to information regarding the strength of the British forces, he underestimated the quality of the British tanks and the skill of the British men. ${ }^{30}$ While intensive training may have taken place in some instances, most of the former POWs remembered long periods of boredom. One interviewee remembered how they spent hours swimming in the Tobruk harbour. Interestingly, he also claimed that they were joined, at times, by their garrison commander, Klopper. ${ }^{31}$ Clearly, the press wanted to create the impression among its readers that the men in the desert were doing well and that their morale was high, but in many cases, the opposite was true. ${ }^{32}$ The men around Tobruk seemed to be surrounded by a general negative atmosphere. As early as October 1941, Edward Dickinson of the Transvaal Scottish wrote in his diary, "the feeling within the detachment just now isn't altogether A1 - there's frequent bickering and quarrels. Don't really know why, except that we're bored." ${ }^{33}$ In April 1942, Dickinson and a friend represented a number of men who complained to their company commander whose leadership style, they believed, negatively affected camaraderie among the men. ${ }^{34}$

Shortly after the fall of Tobruk, the former Australian Prime Minister, WM Hughes, directed his criticism at the press reports, saying, "In Libya the official communiqués have ladled out information like soothing syrup, and by emphasising minor successes they have created the impression that our forces, which actually have been driven slowly back, were on the crest of the wave." ${ }^{35}$ Hughes went on to criticise the effort to maintain home front morale by referring to the overly optimistic tone in press reports as the "daily dope" without which the nation apparently could not sleep peacefully. ${ }^{36}$

The details of the Battle of Gazala and the military events leading up to the encirclement are beyond the scope of this article. That Klopper found himself surrounded by the enemy and in a precarious position on 18 June 1942, was not a situation entirely of his own making. Klopper was in fact absolved of blame for the surrender by a Court of Enquiry that was held soon after Tobruk had surrendered. ${ }^{37}$ The findings of the Court of Enquiry were secret and only became public knowledge decades after the event. The first person to gain access to the Court of Enquiry document and make its findings public via a book was EP Hartshorn. ${ }^{38}$ The Union War Histories Section (UWHS), although not disclosing the findings of the Court of Enquiry in the official history on the fall of Tobruk, nevertheless drew heavily on the document in producing their well-researched account. ${ }^{39}$

The rank and file inside the Tobruk perimeter could not have known Rommel's exact intentions when he moved eastwards past Tobruk in pursuit of the fleeing British who had been mauled in the Cauldron battles. Those manning the extensive Tobruk defences were well aware of the crippling reverses their comrades had suffered at the hands of Rommel in the preceding weeks. Many retreating Eighth Army personnel, including the South African $1^{\text {st }}$ Division under Major General Dan Pienaar, had routed through Tobruk, beating a hasty retreat to the Egyptian frontier. In fact, thousands of those now contained within the fortifications were the remains of a defeated and demoralised army. Unsurprisingly, the majority of Tobruk's defenders disagreed with the journalists' optimistic views of the situation and saw their situation in a very negative light. Regarding the 'strength' of Tobruk, Ike Rosmarin, part of a supply unit with the $2^{\text {nd }}$ SA Division, was of the opinion that the Germans were far superior as far as striking power was concerned and that Tobruk was in "great danger [and Rommel] steadied himself for the kill". ${ }^{40}$

Interviews conducted with former POWs and a reading of their war memoirs make it clear that many of the men considered the Tobruk defences deficient. Michael de Lisle served with the $2^{\text {nd }}$ AntiAircraft Regiment and he believed that the "minefields had not been maintained and defensive positions had filled with sand". ${ }^{41}$ During the interview, he also remembered that on the night before the fall of Tobruk, they were loading their Bofors guns with anti-tank ammunition instead of anti-aircraft 
ammunition. ${ }^{42}$ AJ Cremer, attached to the $2^{\text {nd }}$ SAI Division and a member of the Divisional Headquarters, noted the bad state of the minefields and that the mines themselves were so old that they were completely ineffective. ${ }^{43}$ According to Cremer, both Klopper and De Villiers continually asked for new mines but were told there were no supplies. Additionally, Cremer was under the impression that these two generals were ordered not to use the new mines that were being stored in Tobruk as these were reportedly reserved for the Royal Engineers. ${ }^{44}$ While the relatively small number of former POWs interviewed is by no means a representative sample, most of these men made it clear that Tobruk lacked sufficient weapons and communication equipment to conduct an efficient defence..$^{45}$

Due to the nature of Rommel's attack on the morning of 20 June 1942, in the south-east corner of the fortress, the South Africans who had seen very little action in the desert war thus far, were again deprived of the bulk of the combat. Rommel's assault fell on the Indian Army contingent manning the defences directly in the path of the attack. ${ }^{46}$ The South Africans, consisting of two brigades manning the western and south-western corners of the fortress, were many miles away from the brunt of the action. When Klopper finally ordered a counter-attack on the morning of 20 June, in a vain attempt to restore the situation, it again excluded the South African brigades thus depriving them of a last chance of seeing any action. The South Africans were left languishing while manning defences many kilometres away from the action. When the surrender came, most South Africans had hardly fired a shot in anger and the news of the surrender came as a humiliating surprise. ${ }^{47}$

As the military situation in Tobruk became more desperate, the newspapers expressed concern regarding Rommel's offensive, but attempted to put their readers at ease having a strong regard for public morale. Most reports ended on an optimistic note, in an effort to maintain home front morale. The general optimistic tone of the press was out of kilter with the militarily dire circumstances progressively unfolding. On 16 June 1942, The Times in London reported somewhat pensively of a confused tank battle between Rommel's forces and the Eighth Army, which was at that stage deemed to be "still full of fight". ${ }^{48}$ The first signs of alarm began to emerge when the military correspondent warned that Rommel would set his sights on Tobruk following his successful destruction of the Gazala defences. The correspondent's guarded optimism was tempered by statements that reflected a more realistic view of the battle. For instance, the journalist felt it was "disappointing to observe that [Rommel] enjoys as much freedom as he does to career about behind the Gazala position". ${ }^{49} \mathrm{He}$ also believed that Rommel enjoyed a "slight" advantage over the Eighth Army at that time. Almost as if to contradict himself, the correspondent concluded his article with a final attempt at optimism, saying that Rommel would be found "impotent for serious harm at this occasion". 50

The Daily Mail reported on 19 June that Tobruk was ready "once again for siege [and that Rommel] is expected to launch his major assault". ${ }^{51}$ For the most part, the article gave a realistic view of the dangers facing the Tobruk garrison, but the author of the article could not resist a few sentences of morale boosting and added, "every small observation post [in Tobruk] is manned by men sitting quietly behind anti-tank guns. Others are squatting, tommy guns in hand, waiting." 52 In June 1942, the optimism in the British press seemed unstoppable and even on the day before the defeat, The Times correspondent reported from North Africa that Tobruk is "denied to Axis" ${ }^{53}$ The article goes on to say

One can scarcely resist the conclusion that if Tobruk should now be assaulted it will be put to a test far more severe than on the last occasion. On the other hand, its strength is probably greater than ever. The outside observer, without all the facts at his disposal, would perhaps have decided on evacuation this time, and certainly all one's instincts favour it; but the outside observer generally had the same view last time, and was then wrong. ${ }^{54}$

The Reuters report, also published in The Times on 20 June 1942, revealed a similarly cheerful point of view, by stating, "pressure on Tobruk at present is slight, as Rommel has thrust his main forces east 
towards Egypt from El Adem". ${ }^{55}$ The fact that the British press believed that Rommel was focusing on Egypt at this stage, reveals the extent to which they and the rest of the Eighth Army were misinformed. Rommel's bypassing of Tobruk was part of an elaborate subterfuge designed to lull the defenders into believing that the DAK was making its way toward Egypt as a first priority. ${ }^{56}$

In South Africa, the reports in the English newspapers were very similar to each other. The Pretoria News announced that Rommel's "eastward advance" had been stopped and that Auchinleck planned to hold Tobruk. ${ }^{57}$ The Rand Daily Mail cheerfully reported, "Springboks based in Tobruk harass Axis". ${ }^{58}$ Both these newspapers also reported on Smuts who had addressed men at a passing-out parade. In his speech to the newly trained soldiers, Smuts prophetically referred to the "ordeals, tests and blows" that these men would have to withstand once they entered active service. ${ }^{59}$ It would not be too far-fetched to assume that Smuts was thinking of the dire situation at Tobruk when he spoke those words. ${ }^{60}$ Die Burger's SAPA report on the front page also stated that Rommel was moving towards Egypt, but alongside the main article, it placed the German and Italian communiqués, which stated that Tobruk had been surrounded by Axis forces. The Transvaler, a nationalist newspaper with HF Verwoerd as editor, put it more bluntly by reporting that the Eighth Army had been cut in two. ${ }^{61}$ This was indeed a more accurate description of the situation, as the main part of the Eighth Army had by now retreated to the Egyptian frontier, leaving the South Africans under Klopper isolated and surrounded in Tobruk.

At the time of the evacuation, the South Africans, including Major General Frank Theron, the officer commanding (OC) of the Union Defence Force's Administration in the Middle East, was under the impression that the Eighth Army would hold a defensive position between Acroma and El Adem, both of which were positions towards the west of Tobruk. ${ }^{62}$ As the press was informed by the headquarters in Cairo that this was indeed the situation, they reported it as such. However, both Cairo and the press were wrong. Clive Luyt, former POW and a member of the $2^{\text {nd }}$ Anti-Aircraft Regiment, summed up Rommel's advance as -

then the Germans broke the Gazala line and then marched, and Rommel then passed Tobruk and we thought, $\mathrm{O}$ well, this is fine, we were going to be all right here, and then the party turned around and attacked from the East side, we were in then, and we were all captured, the whole lot of us. ${ }^{63}$

Michael de Lisle remembered that, before the surrender, the situation was characterised by "complete chaos and confusion inside and we were pushed around during the night before the surrender and ended up on the 21 st of June on the Western perimeter loading our guns with anti-tank ammunition instead of anti-aircraft ammunition". ${ }^{64}$ While De Lisle's regiment still had ammunition at the time of the surrender, Bill Hindshaw remembered that not only did they not have any ammunition, "the conditions were terrible, there was no communication, there was nothing, nothing, nothing" ${ }^{65}$ Although these former POWs could not have known Rommel's true intentions at the time, their recollections show that the men in the Tobruk garrison were also under the impression that Rommel had moved east of Tobruk and that the South Africans would remain in Tobruk for the time being.

In the British and English press reports, readers could also come to the conclusion that Tobruk had been encircled by Rommel, but the reporters seemed to be so aware of their duty regarding morale, that the impression was created that Tobruk was not threatened. One of those positive aspects on which the English press concentrated at the time was the successful evacuation from Gazala, a town to the west of Tobruk. It is also likely that Hughes, in his criticism of the communiqués from Libya, was referring in part to the Gazala reports when he mentioned the "daily dope", or propaganda in newspapers. ${ }^{66}$ Most Reuters and SAPA articles viewed the evacuation from Gazala as an achievement, for instance, the Rand Daily Mail reported "Springbok's cool courage thwarted fierce Axis Attacks" 
referring to the evacuation. ${ }^{67}$ It is possible that these attempts at keeping up morale by looking at the evacuation of Gazala diverted readers' attention away from the seriousness of the Tobruk situation.

\section{Surrender of Tobruk, 21 June 1942, and immediate home front reactions}

There were opportunities available to Klopper other than unconditional surrender. Klopper seriously considered a breakout of the surrounded garrison, which may have resulted in the bulk of the South Africans escaping back to British lines. Due to the large proportion of the transport vehicles falling into Rommel's hands, he then entertained the idea of a final stand. This option, although attractive from the point of view of redeeming honour, would have resulted in many casualties. Placed on the horns of the dilemma and wishing to prevent unnecessary casualties, he chose to surrender. Klopper maintained that his orders were for the troops to surrender on fronts where the Germans were attacking, but all men who wished to escape had to be given every facility. He said it was a great shock to him that so few men attempted to escape. On the other hand, he deplored the conduct of the Coldstream Guards in passing out of the perimeter of Tobruk at 16:00 on the 20 June, without orders and without authority, taking with them some of the precious antitank guns. ${ }^{68}$

The press and the public, deprived of the findings of the Court of Enquiry, were left to their own devices to construct the events according to the very limited knowledge they possessed. A more accurate picture of the events surrounding the surrender of Tobruk would only emerge a decade after the event with the release of the official history by the UWHS ${ }^{69}$ Until the release of the official history, the details of the surrender would remain the subject of speculation and the sole preserve of the combatants and POWs. Klopper was unfortunate in having to face the might of the Afrika Korps very much alone. However, it was his ineffective conduct of the Tobruk defence, coupled with the alacritous nature of his surrender that drew the ire of the POWs and set the scene for a progressively more critical press. $^{70}$

In South Africa and Britain, the fall of Tobruk held political ramifications for both prime ministers. Not only was the defeat a great embarrassment to the Allies, but the British public had become increasingly critical of Churchill's military strategy and the string of military defeats under his premiership. ${ }^{71}$ Only $35 \%$ of the public indicated in a survey that they approved of the strategy for the conduct of the war. ${ }^{72}$ Furthermore, Churchill faced a censure motion tabled by Sir John Wardlaw-Milne in the wake of the surrender of Tobruk. ${ }^{73}$ The Australians were especially critical of the defeat and the inevitable comparisons were made with their successful defence of Tobruk the previous year. Klopper's surrender in one day is often compared to the previous siege, endured under similar circumstances, where the Australians managed to hold Rommel at bay for 244 days until the siege was lifted. ${ }^{74}$

On the home front, in Britain and in the Union of South Africa, newspapers reported the fall of the harbour town as "unexpected" ${ }^{75}$ This raised many questions and the public wanted answers from politicians and military leaders. ${ }^{76}$ Rommel's victory at Tobruk was indeed a matter of great concern, both in a military sense and with regard to home front morale. With Tobruk in his hands, Rommel's next target was the British stronghold of Egypt and beyond. The German military was riding the crest of a wave having launched Operation Blue in June 1942 making immediate and massive gains towards Stalingrad and the oil-rich Caucasus. The British failure at Tobruk, combined with another unstoppable German offensive in Russia, added to the general Allied home front gloom. ${ }^{77}$

Given the military context of the time, it is understandable that Churchill, who was both British prime minister and minister of defence, referred to Tobruk as "one of the heaviest blows" of the war. ${ }^{78}$ The news of the embarrassing surrender had come to him via President Roosevelt while on a visit to the United States. According to Field Marshal Alanbrooke, chief of the Imperial General Staff, the news 
delivered personally by Roosevelt to Churchill came as a "staggering blow". ${ }^{79}$ For Smuts, the political and military situation was equally dire, and he immediately embarked on the Avenge Tobruk recruitment campaign to replace those UDF soldiers who were lost or captured at Tobruk. ${ }^{80}$ Smuts also took pains to show that the Union's support for Britain would not be disrupted by the Tobruk disaster. ${ }^{81}$

This immense military setback resulting in the capture of thousands of UDF soldiers had to be managed carefully in limiting the disruption to home front morale. Furthermore, military setbacks of this magnitude could dissuade potential new volunteers from joining the UDF exacerbating an already acute shortage of military manpower. This was especially relevant to the Afrikaner section of the population, some of whom felt more at ease ideologically with Germany than with Britain. South Africa's divided political environment reflected divergent viewpoints on the ultimate responsibility for the surrender of Tobruk. The anti-war lobby felt that the South Africans had been sacrificed needlessly by British military ineptitude while some of the pro-war lobby were suspicious that Klopper was disloyal to the cause and had handed Tobruk over without a fight. The reaction of the New Zealanders who suffered similarly in the campaign is insightful. The New Zealand official history describes the New Zealand Division as "... injured, puzzled, and to some extent ill-used ..." in the aftermath of Operation Crusader. ${ }^{82}$ Lt Gen. Bernard Freyberg, who commanded the $2^{\text {nd }}$ New Zealand Division in North Africa, was influenced by his experience with the British in previous campaigns. Coupled with their conduct of Operation Crusader, he was convinced that it was in the interest of New Zealand to get its forces out of the desert campaign altogether. Freyberg was not alone in disagreeing with British methods of dividing divisions into brigade groups, a view shared by Brink, whom he describes as “... in despair over dissipation of his forces and manner in which his brigades are employed even without reference to him". ${ }^{83}$ As a result of British "faulty" ideas, Freyberg had his division transferred to Syria to "... safeguard the interests of New Zealand and of the Division". ${ }^{84}$ Bitterness was rife amongst the troops who had surrendered with Klopper and many believed that he had betrayed them. ${ }^{85}$

When the news of the defeat reached Britain, The Times initially declared that the fall of Tobruk was not as great as some of the previous losses that the Allies had suffered, but that the "suddenness makes the shock heavier than that of almost any of them". ${ }^{86}$ The "suddenness" probably referred to Klopper's quick surrender, creating the impression amongst readers that earlier reports on Tobruk's defences were indeed correct and that Klopper surrendered without good cause. On the same day, the newspaper also reported that the fate of the South African garrison at Tobruk was still unknown, but it nevertheless quoted the German High Command Broadcast, which stated that 25000 prisoners were taken. In contrast, the Daily Mail bluntly announced, "Tobruk and Bardia are lost" and that 25000 Allied soldiers had been taken prisoner. ${ }^{87}$

\section{The aftermath of the surrender of Tobruk}

The loss of the $2^{\text {nd }}$ Division at Tobruk obliterated 33\% of South Africa's fighting power in North Africa in an instant. This was a situation from which the country's military struggled to recover for the remainder of the war. ${ }^{88}$ In the weeks following the surrender, the remaining South Africans suffered near to the lowest morale in the Eighth Army. ${ }^{89}$ Pienaar, who commanded the $1^{\text {st }}$ SAI Division at El Alamein, was extremely jittery in the wake of Tobruk and inspired little confidence in his British superiors. ${ }^{90}$ The surrender of Tobruk unnerved Smuts and in the face of a rampant Rommel at the head of his DAK, he had every reason to fear for the survival of the remainder of his war-weary troops. In November 1942, on his way back from London, Smuts reviewed his troops in North Africa and told them that they would be brought back to South Africa for their training and re-equipment as an armoured division. ${ }^{91}$ Smuts's announcement that the division would be brought back to South Africa, at the height of the battle of El Alamein, was surprising and to some senior British officers, unwelcome. ${ }^{92}$ Smuts had 
an eye to the impending 1943 election and any further battlefield losses risked his chances of a victory at the polls. ${ }^{93}$

Within days of the Tobruk surrender, allegations began to emerge in South Africa and Britain of the cowardice and treachery of the garrison. ${ }^{94}$ The British press did not distinguish between the garrison commander and his men, and were vociferous in their condemnation citing the catastrophe as a fiasco and a humiliating disaster. Fortunately for South Africa, the press made little reference to the fact that the garrison was commanded by a South African and contained a large proportion of South African troops. ${ }^{95}$ When the fact that Tobruk was commanded by a South African general was revealed by Churchill, it caused consternation in the South African camp, which saw this as an indictment and a "significant imputation of blame". The rumours of fifth columnists and defeatism surrounding the surrender prompted the reaction that "... timely action [be taken] to controvert libels which may stick to South Africa through history". ${ }^{96}$

In the days following the Allied defeat at Tobruk, the focus of The Times shifted towards the military capacity and strength of the garrison at Tobruk. On 23 June 1942, The Times declared that "lessons" could be learned from the events at Tobruk and pointed out that "the Allied forces were everywhere faced with tanks and anti-tank guns of superior range and hitting power to their own". ${ }^{97}$ Once again, the Daily Mail was more direct with an article by Alexander Clifford that was accusatory in tone, saying, "Our troops were not rightly handled." ${ }^{98}$ Clifford's article stated clearly that the Eighth Army had sufficient supplies and an advantage with regard to its position, but it made the point that as a whole, the army did not "function like a well-trained professional army" and that one of the main problems was the speed at which the different garrisons and divisions were able to communicate with each other. ${ }^{99}$ With regard to the South Africans at Tobruk, Clifford mentioned that

the predestined garrison shut itself up inside the perimeter and left half a dozen strong [defensive] "boxes" outside [...] we had good troops inside Tobruk. They had tanks and guns and stores. The defences were almost ready made for them. They were fairly fresh troops, and Rommel could only bring against them troops which had already been fighting daily for nearly a month. The Australians with far less preparation and material had held it last year. It had seemed certain that this new garrison could hold off any attack at least for a few days ... ${ }^{100}$

While the accusations in Clifford's article was aimed at the commanders of the Eighth Army and to some extent also to the political leaders, the extract on the Tobruk garrison may have seemed to lay some of the blame with the South African garrison. It is ironic that these extracts also show to what extent the correspondents viewed the situation before the fall of Tobruk as obviously precarious, whereas before they had focused on the good spirits among the men and their military preparedness to fend off dangers.

In South Africa, The Pretoria News presented its readers with Smuts' view on the disaster. With the political divisions in mind, Smuts realised that it was important for him to focus on the positive aspects of the defeat. He therefore placed emphasis on the participation of the UDF soldiers by saying they "held to the last the defences in the Tobruk perimeter [and] they upheld the fighting tradition of the South African Army". ${ }^{101}$ Smuts, referring to the "fighting tradition" of South Africa, was employing a similar propaganda tactic that he had used to considerable effect in earlier recruitment drives, when he attracted the attention of potential Afrikaans-speaking volunteers by reminding them of Boer War battles fought by their ancestors. ${ }^{102}$ Die Vaderland concentrated on the German communiqués, which they received from the United Press war correspondent and emphasised the fact that Rommel was now ready to attack Egypt and that there was a lack of fighting spirit among the men of the Eighth Army. ${ }^{103}$ Die Burger's front-page article of 22 June was a basic translation of the Reuters article, but on 24 June, it published a more cynical article on page four. The anonymous author stated that when the British 
press announced that everything was under control, the reading public should have expected bad news to follow, as this propaganda tactic had become the norm in the English press. ${ }^{104}$

On 23 June 1942, the Daily Mail provided their readers with international perspectives on the fall of Tobruk, and without a doubt, the finger was firmly pointed at "British strategy, faulty leadership and a lack of plans". ${ }^{105}$ The Swiss, for instance, accused the British of being unimaginative and suffering from a "chronic inferiority complex". ${ }^{106}$ Many newspaper articles on the military situation in the weeks before the fall of Tobruk are reminiscent of what Paul Fussel refers to as the "British tendency towards heroic grandiosity about all their wars". ${ }^{107}$ By employing the passive voice and euphemisms, for example, describing Tobruk as a town that "has been effervescing with British counter-measures", 108 the military authorities, war correspondents and their editors tried to convince their readers that soldiers were heroic men fighting for a moral cause. This technique of avoiding realistic and accurate descriptions of battle scenes and war was used to great effect during the First World War, but it seems that it still had a place in the press during the Second World War. Euphemistic phrases may have been creative in a literary sense, but the potential of such a phrase to create the wrong impression among readers is obvious. Additionally, descriptions such as these are in stark contrast to what Fred Geldenhuis remembered when his regiment entered Tobruk six days before Rommel's victory. Geldenhuis recalls that the town was "deserted" and that there were "no anti-aircraft guns pointing into the air, just empty gun pits". ${ }^{109}$ Geldenhuis's description is certainly not one of a town effervescing with military preparation.

On 2 July 1942, The Times declared that the "Fall of Tobruk [was] quite unexpected", and pointed out that Auchinleck "believed that the [South African] garrison was strong enough to hold the fortress until he had built up his strength and reorganized his forces to launch a counter-attack" against Rommel. ${ }^{110}$ These statements formed part of an article which reported on Lord Wardlaw-Milne's censure motion against Churchill and in which Wardlaw-Milne proposed that the office of the prime minister and that of minister of defence, both of which were held at the time by Churchill, should be separated. Although the censure motion was not successful, it did make it clear that the British government could not afford another defeat at the hands of the Axis. ${ }^{111}$

While the veterans' opinions are no doubt influenced by retrospective knowledge and, in some cases, partial loss of memory, they do share an almost universal negative appraisal of the military situation. In addition, the shock of surrender and of being captured can be considered as "flashbulb memory", which, as defined by Berntsen and Rubin, "[are] vivid and detailed memories of the moment when one first learned the news of an important, and typically shocking, public event". ${ }^{112}$ Although the former POWs described the battle as chaotic, they were also able to describe specific events during the battle in precise detail.

For those taken prisoner by Rommel's forces, the sense of shock was soon followed by experiences of deprivation, hunger and thirst as they were marched to various temporary camps in Tobruk and Benghazi. Shortly after capture, the POWs were handed over to Italian forces who were clearly not equipped to deal with thousands of prisoners. By December 1942, most of these captives were loaded onto cargo ships and transported to Italy, where conditions improved once the POWs starting receiving Red Cross parcels. ${ }^{113}$

For the most part, the experience of the South African POWs was very similar to that of other Allied POWs in Europe. Two aspects however, set the experience of the UDF men apart. Firstly, Afrikaans-speaking POWs found that their language isolated them to a degree from their fellow prisoners. ${ }^{114}$ Secondly, there was the issue of Tobruk. Interviews with former POWs show that these men placed noticeable emphasis on the matter of blame, directed either at Klopper, the British High Command or at themselves. The aspect of blame is also notable in the memoirs of former POWs. A 
number of the men blamed the top command for the defeat, while others blamed the British directly for the fall of Tobruk. One POW went so far as to say that the British forces abandoned the South Africans in Tobruk, while others blamed the British for the lack of materiel. ${ }^{115}$ Wessel Oosthuizen of the Police Brigade placed the blame directly with the British who, in his opinion, promised to send extra forces to Klopper's garrison, something which never happened. ${ }^{116}$ The view that the Eighth Army would send reinforcements to Tobruk was apparently shared by Klopper, who in his 1950 Huisgenoot article stated he was ordered not to try to break out of Tobruk as he was to wait for the Eighth Army. ${ }^{117}$

Directly following their capture, many Union volunteers blamed Klopper, who apparently tried to address them in the days after the battle. The rank and file made their feelings obvious as they turned their backs on him as he approached. ${ }^{118}$ Clive Luyt believed that the fall of Tobruk was inevitable because -

... [they] sat up in the desert with no boss, no top leader who could inspire us. To the best of my knowledge, while the Germans had General Rommel in charge of them and in a tank and probably in the front line, our chaps were all sitting round a round table in Cairo, trying to run the war from Cairo. Whether that is true or not I don't know but we had no real leader, until they suddenly sent Klopper who was straight from a desk in Pretoria. He was General Klopper, he had military experience, or a certain amount of experience, but not war-time experience. They sent him up. They stuck him in charge of Tobruk and about three days later, Rommel and co attacked Tobruk and we all ended in the bag. ${ }^{119}$

Negative opinions about their own participation, or lack thereof, also became evident during interviews with POWs. De Lisle was left with a feeling that "you've never done well", while Fred van Alphen Stahl believed they "didn't go down fighting". ${ }^{120}$ Becoming a POW caused great regret for Stahl and more than once during the interviews, he expressed his desire to have been on the "winning side [...] not on the bench, you would have liked to been in the scrum at that time". ${ }^{121}$

Rex Woods, the author of Night train to Innsbruck, ${ }^{122}$ sums up the feeling amongst those captured at Tobruk as well as other South Africans:

To their everlasting indignation, the flower of South Africa's volunteer army - many of whom had distinguished themselves in action in Abyssinia during the capture of Addis Ababa from the Italians and, more recently, at the capture of Bardia and in the Gazala line in the Libyan desert now found themselves inexplicably ordered to lay down their arms at Tobruk without, in most cases, being allowed to fire a shot. Their previous good record made this a particularly bitter pill for them to swallow - the taste of which was bound to linger, despite the subsequent distinction with which their more fortunate compatriots fought at El Alamein and then in the battles of the fierce and a protracted campaign in Italy. ${ }^{123}$

Once inside POW camps, the tables were turned on the Union POWs as they now faced recriminations and accusations from POWs of other Commonwealth nationalities for the defeat at Tobruk. Throughout his captivity, Brokensha remained convinced that especially his fellow British POWs harboured resentment against the South Africans as a result of the loss of Tobruk. ${ }^{124} \mathrm{He}$ remembered how "snide remarks" about Tobruk would lead to fights among POWs. ${ }^{125}$ Even those South Africans not involved in the Tobruk battles seemed to have suffered as a result. Bernard Schwikkard of the $3^{\text {rd }}$ Battalion, Transvaal Scottish, was captured at Sidi Rezegh in November 1941, experienced criticism from prisoners of different nationalities as a result of the setback at Tobruk. According to Schwikkard, there existed "tremendous camaraderie" between POWs of different nationalities, but then

all these chaps from Tobruk arrived [...] now there was this deep hate, almost belligerent, against the South Africans, Why? The British. Because they felt that Klopper had surrendered, they should have gone on fighting. And they blamed South Africa for their predicament. And they felt that we were almost cowards [...] and then this suddenly arose, this anti-South Africa feeling. ${ }^{26}$ 
And what of Klopper who together with his dejected men found himself in captivity? His feelings were made known in an interesting broadcast by the German propaganda radio station on 20 July 1942 in which Klopper allegedly took exception to the British Radio Daventry report that Tobruk was of no importance. He found this to be an insult to the honour of those who defended Tobruk and folly to say that the defenders were sacrificed for nothing. ${ }^{127}$ This message of a callous British disregard for the life of Dominion troops must have resonated with a large proportion of the Radio Zeesen listeners, who were predisposed to opposing the war effort. ${ }^{128}$ A number of pro-war supporters in South Africa judged Klopper harshly, with suggestions in certain quarters that he was not loyal. Major George Bastin, who served with Klopper up to the last moments before the surrender of Tobruk, found it necessary to address a letter to Van Ryneveld defending Klopper's honour and expressing anguish at the malicious gossip circulating in South Africa. None other than Klopper's brother, who was a preacher in George, apparently felt the contempt of the local jingoes. ${ }^{129}$

With the Italian armistice of September 1943, many POWs escaped as their guards simply abandoned their prison camps. ${ }^{130}$ Amongst the many escapees was Klopper. His rescuer was none other than Lt Col. Vladimir Peniakoff, better known as 'Popski' of Popski's Private Army. When Klopper introduced himself as the commander of the South African Division and general in command of Tobruk, Popski replied, "I have heard a lot of gossip, mostly malicious. You will soon realise that many uninformed people like me are under the impression that you surrendered too easily." ${ }^{131}$ Klopper replied that he knew and wanted to get back to South Africa as soon as possible to face the court of enquiry, which had been convened shortly after the surrender, indicating a burning desire to clear his name. ${ }^{132}$

Klopper did return to the Union, and many other POWs reached the safety of Switzerland. However, a large number of POWs decided to remain in their camps, most often as a result of rumours that the Allies were working on a plan to set them free. Were it not for disagreements between the War Office and $\mathrm{MI}^{133}$ regarding orders to POWs in Italian captivity, many more would probably have escaped. ${ }^{134}$ For many escapees, freedom in Italy was short-lived, as the German forces quickly surrounded the camps and transported the POWs to camps further north to Germany, Poland, Austria and Czechoslovakia where they remained until the end of the war.

\section{Conclusion}

This article focuses on the fall of Tobruk in June 1942, seen through the eyes of those who experienced the event first-hand, as well as through the lens of the media who reported the event. This is a departure from how the fall of Tobruk has been depicted by the vast majority of campaign histories on the subject. The study reported here traced the shift in the manner in which the press reported the military situation at the outset of the battle to its more critical approach once Tobruk had fallen. At the outset of the battle, there was a yawning gap between optimistic reports of the press and the trepidation felt by the soldiers at the front. What has come to light is the inexorable convergence of press opinion and the opinions of the POWs about the poor performance of those who led the Eighth Army. This steady convergence of opinion between press and POWs was traced by the study from the outset of the battle to the eventual fall of Tobruk.

The surrender of Tobruk was yet another disastrous event in a series of catastrophes that had been suffered by the Allies at the hands of the Germans since the start of the Second World War. The Wehrmacht was at the peak of its military prowess in 1942, with its forces driving deep into the Russian steppes making its way towards Stalingrad and the rich oilfields of the Caucasus. In the face of all these military setbacks, the press had the enviable duty of trying to boost home front morale. The press were also severely restricted by their governments in the manner in which they were allowed to present 
information on the progress of the war effort. The soldiers who had to face the Germans in the desert were considerably less optimistic than reported back on the home front. As the Germans drew nearer to Tobruk, the soldiers manning the defences suspected that they were less well prepared to meet Rommel than the optimistic press reports would have the home front believe.

Overly optimistic press reports on the military situation in the Western Desert in the days before the fall of Tobruk created a false sense of security among the readers of the British and Union newspapers. Although some of the South African newspapers held opposing views on the country's participation in the war, most of their front-page articles on the war came from one source, Reuters. Therefore, most Afrikaans- and English-speaking readers, regardless of their personal or political feelings on the war, would have been reassured by these reports that the Allies were in a strong position regarding Tobruk. The high hopes of the readers were then promptly crushed when Rommel took the harbour town and captured thousands of Allied soldiers. In an attempt to remedy the situation for the sake of home front morale, the newspapers demanded answers and reported widely on the parliamentary debates that followed the disaster. In view of the previous Allied defeats and the importance of British home front morale, it was not surprising that the British press looked for a scapegoat when the victory they had led their readers to expect, ended in a humiliating defeat. In the Union, the home front was not as directly affected by the war as was the case in Britain, as many South Africans hardly noticed when the war affected food supplies. Morale and propaganda efforts in South Africa were therefore aimed at unity within the country, while in Britain it was directed towards withstanding the Nazi onslaught. ${ }^{135}$

It was the disparity between reality and what was presented in the press to the public that created the false sense of reassurance. This mismatch was the result of propaganda efforts to maintain positive public morale; yet, it was precisely this situation that caused recriminations once the outcome of the battle had become clear. Ironically, the British efforts to maintain positive morale among the civilian population on the one hand, and good relations with the Union on the other, created a press debacle that was almost equal to the military disaster that took place in Libya. By demanding answers from government and by focusing on the parliamentary debates and the possible unseating of Churchill, the press and the propaganda ministry tried with varying success to redeem the situation.

Relief from a fragile political situation for both Smuts and Churchill came in the form of a turning of the military tide in favour of the Allies. Once victory had been registered at El Alamein in November 1942, the debacle of Tobruk was soon forgotten. Further German setbacks at Stalingrad and in North Africa bolstered the home front morale in South Africa and the United Kingdom. For once, press optimism reflected accurately on what was happening on the ground. It was certainly an easier task reporting the numerous victories at hand than having to explain away the many military defeats suffered in the past.

The POWs captured at Tobruk were not able to recover from the humiliation of defeat as fast as those on the home front. For them, the benefits of victory brought little in the way of a relief from the difficulties of their internment. Former POWs interviewed during 2010 and 2011 were negatively affected by the surrender and subsequent experiences of captivity. Dealing with the shock and shame of surrender and then having to listen to accusations of cowardice from fellow POWs, modified how they remembered their life in POW camps and determined, to an extent, the information they chose to share with the interviewer years after the event.

N Tamkin. "Britain, the Middle East and the 'Northern Front', 1941-1942". War in History 15/3. 2008. 315.

This number includes one general and seven brigadiers and what has been described as large deposits of arms, munitions, materials and foodstuffs. Michael Carver is more specific stating a figure of 2000 tons of petrol, 2000 servicible vehicles, 5000 tons of food and large quantities of ammunition. M Carver. Tobruk. London: BT Batsford, 1964, 248. 
3 'The Cauldron' refers to the battles that occurred between 28 May and 14 June 1942 when Rommel inserted his forces behind the Gazala lines where the British lost a major portion of their armoured forces in a series of attacks designed to remove him when they were repelled with huge losses.

4 Carver provides an insightful analysis as to the opening sequences of the Gazala battles. Carver op. cit., pp. 170-192.

5 Operational Order No. 23, codenamed 'Freeborn', dated 10 May 1942, states in the opening paragraph that should the defence of Gazala line become untenable, the entire corps was to withdraw to the Egyptian frontier. Allowance was made for the withdrawal of the Tobruk garrison to Bir El Hariga close to the Egyptian frontier. DOCD, UWHS - Civil, Box 371 Operations in the Western Desert, Part III, p. 31, Report of Tobruk Court of Enquiry, 27 May-2 July.

6 TNA, WO 32/10160/360, Auchinleck despatch on operations in the Middle East, 1 November 1941 to 15 August 1942.

7 C Barnett. The desert generals. New York, NY: Viking Press, 1961, 153. Churchill in a signal to Ritchie: "Presume there is no question in any case of giving up Tobruk. As long as Tobruk is held no serious enemy advances into Egypt is possible ...".

8 JAI Agar-Hamilton \& LCF Turner. Crisis in the desert: May-July 1942. London: Oxford, $1952,107$.

9 The Germans have produced a belated but excellent official history by B Stegemann, G Schreiber \& D Vogel. Germany and the Second World War: The Mediterranean, South-east Europe, and North Africa 1939-1941. Oxford: Oxford, 1995, III. The Italians have also produced an official history by M Montanari. Le Operazioni in Africa Settentrionale (Marzo 1941-Gennaio 1942). Rome: Ufficio Storico, 1993, II. The British official history is well served by ISO Playfair. "The Mediterranean and Middle East". In J. Butler (ed.), A history of the Second World War. Uckfield: Naval \& Military Press, 2004, III. The South Africans have their excellent official history produced by the Union War Histories Section, Agar-Hamilton \& Turner op. cit. There are a plethora of campaign histories, the best being that of Michael Carver and Corelli Barnett: Carver op. cit.; M Carver. Dilemmas of the Desert War: A new look at the Libyan Campaign 1940-1942. London: BT Barsford, 1986; Barnett op. cit.. The best regimental history covering Gazala is BH Liddell Hart. The Tanks: The history of the Royal Tank Regiment. London: Cassel, 1959.

10 For a South African perspective on Tobruk, see the author's article: DB Katz. "The greatest military reversal of South African arms: The fall of Tobruk 1942, an avoidable blunder or an inevitable disaster?". Journal for Contemporary History 37/2. 2012. 71-104.

11 See for instance B Moore \& K Fedorowich. Prisoners of war and their captors in World War II. Oxford: Berg, 1996; B Moore \& B Hately-Broad (eds). Prisoners of war, prisoners of peace: Captivity, homecoming and memory in World War II. Oxford: Bloomsbury Publishing, 2005; B Moore \& K Fedorowich. The British Empire and its Italian prisoners of war, 1940-1947. London: Palgrave Macmillan, 2002; B Moore. "Unwanted guests in troubled times: German prisoners of war in the Union of South Africa, 1942-43". The Journal of Military History 70/1. 2006. 63-90; SP Mackenzie. The Colditz myth: British and Commonwealth prisoners of war in Nazi Germany. Oxford: Oxford University Press, 2004; WW Mason. Prisoners of war Official History Prisoners of war New Zealand in the Second World War 1939-45. Wellington: War Branch Department of Internal Affairs, 1954. AJ Kochavi. Confronting captivity: Britain and the United States and their POWs in Nazi Germany. Chapel Hill, NC: University of North Carolina Press, 2005; A Gilbert. POW Allied prisoners in Europe 1939-1945. London: John Murray, 2007.

12 For a perspective on South African POW's, especially those captured at Tobruk, see the author's article: K Horn. "Narratives from North Africa: South African prisoner-of-war experience following the fall of Tobruk, June 1942". Historia 56/2. 2011.94-112. It can be argued that at all the belligerents were 'racist' at the time, in that black soldiers were treated differently than white ones. Even the Geneva Convention did not consider it necessary to treat black POWs in the same way as white POWs. However, in the case of South Africa, it was a question of degree.

13 C Birkby. Uncle George: The Boer Boyhood, Letters, and Battles of Lieutenant-General George Edwin Brink. Johannesburg: Jonathan Ball, p. 243. Birkby was a correspondent with the South African Press Association's war correspondent in East Africa and later, the Western Desert.

14 P Summerfield. "Dunkirk and the popular memory of Britain at War, 1940-1958". Journal of Contemporary History 45/4. 2010. 788; Gilbert op. cit., p. 128.

15 Summerfield op. cit., p. 789.

16 G Eley. "Finding the people's war: Film, British collective memory, and World War II". The American Historical Review 106/3. 2001. 818-838.

17 J Harris. "War and social history: Britain and the Home Front during the Second World War". Contemporary European History 1/1. 1992. 20.

18 R Mackay. Half the battle: Civilian morale in Britain during the Second World War. Manchester: Manchester University Press, 2002, 176.

19 Ibid., p. 146. 
20 T Oliver Boyd-Barrett. The globalization of news. London: Sage, 1998, 155.

21 E Bielsa. "The pivotal role of news agencies in the context of globalization: A historical approach". Global Networks 8/3. 2008. 351.

22 E Hartshorn. Avenge Tobruk. Cape Town: Purnell, 1960, 137. The Tobruk Court of Inquiry was convened within a few months after the surrender of Tobruk in 1942. It was agreed by Smuts and Churchill to keep the details of the findings secret. The actual document is found at DOCD, UWHS - Civil, Box 371 Operations in the Western Desert, Report of Tobruk Court of Enquiry, 27 May-2 July.

23 J Macleod. "Introduction". In J. Macleod (ed.), Defeat and memory: Cultural histories of military defeat in the modern era. Hampshire: Palgrave MacMillan, 2008, 8. Jenny Macleod posits that amnesia in the face of profound trauma can be healthy for national unity and for the individual. This contrasts with the desires of historians who find this untenable and seek instinctively to fill the lacuna. Sidi Rezegh and Tobruk would have overburdened the national trauma of a divided South Africa, had the full extent of the defeat been revealed immediately after the battles. By the time the general public had gained access to the details of these events, their impact had substantially diminished in the face of subsequent victories. DOCD, Personal records, Record of Sevice H.B. Klopper (1926-1945).

25 His short duty as Brigade Commander of $3^{\text {rd }}$ Brigade from January to May 1942 took place in a relatively quiet period of the Desert War where both sides where building up their combat strength.

26 Klopper's inexperience was matched by that of his Chief of Staff, Lieutenant-Colonel Kriek, who lacked in operational experience and in high grade staff training. DOCD, UWHS - Civil, Box 366, File PMH62N/3, Narrative on the crisis at Tobruk.

27 Military correspondent. "Rommel on the move in Libya". The Times. 28 May 1942. 4.

28 Ibid.

29 Ibid.

30 SAPA. "Verwoede stryd om gapings in Britse Linie". Die Burger. 3 Junie 1942. 1.

31 D Brokensha. 2007. Brokie's way: An anthropologist's story. Love and work in three continents. Fish Hoek: Amani Press, 2007, 67.

32 J Fennell. Combat and morale in the North African Campaign the Eighth Army and the path to El Alamein. Cambridge: Cambridge University Press, 2011, 44. According to Jonathan Fennell, there was a correlation between low morale and willingness to surrender among Allied soldiers in the Eighth Army. Fennel concludes, "certain elements of the Eighth Army were more likely to fight it out than others".

33 T Shearing \& D Shearing (eds). From Jo'burg to Dresden: A World War II diary by EB (Dick) Dickinson. Mossel Bay: Privately Printed, 2010, 40-41.

34 Ibid., p. 61.

35 Correspondent. “'Soothing syrup' in war reports”. The Times. 23 June 1942. 3.

36 Ibid.

37 "Report of Court of Enquiry: Operations in the Western Desert 27 May-2 July". Tobruk Court of Enquiry, DOCD, CGS 22/1, 1942.

38 Hartshorn op. cit., p. 125.

39 Agar-Hamilton \& Turner op. cit. The UWHS copy of the Court of Enquiry was in fact the one that Hartshorn would make use of in his book

$40 \quad$ I Rosmarin. Inside story. Cape Town: WJ Flesch, 1999, 10.

$41 \quad \mathrm{M}$ de Lisle. Over the hills and far away: My twenties in the forties. Unpublished memoirs, n.d., 19.

42 Interview with Michael de Lisle, 4 June 2010, Cape Town.

43 This is in contradiction to some of the findings of the Court of Inquiry, where evidence was given as to the satisfactory nature of the minefields and perimeter wire. Klopper himself states that indeed there were whole minefields lifted for use at Gazala and Knightsbridge, but said that they had been replaced, denying that the minefields were in a poor condition at the outset of the siege. UWHS, DOCD, UWHS - Civil, Box 363, File PMH62C, Reports of South African Officers, Interview with Brigadier HB Klopper (Notes on Major Turner's interview), 6 May 1946.

44 AJ Cremer. Oorlogsherinneringe. Unpublished memoirs, n.d., 16.

45 Interview with Mathys Beukes, 2 February 2011, Bloemfontein; interview with Clive Luyt, 19 May 2010, Cape Town; interview with Stanley Smollan, 15 March 2010, Johannesburg; interview with Fred Geldenhuis, 9 July 2010, Pretoria; interview with Wessel Oosthuizen, 4 December 2010, Hartenbos; interview with William (Bill) Hindshaw, 19 March 2010, Johannesburg.

46 The main effort of Rommel's attack fell on the Camerons and the Mahrattas, both remnants of the 'Cauldron' battles in the opening phases of the Gazala battles.

47 Agar-Hamilton \& Turner, op. cit. The Union War Histories Section under Agar Hamilton produced the official history on the fall of Tobruk as the first of three volumes. The efforts of the UWHS resulted in what is a definitive work on the fall of Tobruk and remains to this day as locus classicus. 
48 Special correspondent. "Axis drive to cut off Gazala salient claim to have reached coast, strong British counter-attacks, Eighth Army 'adjusting its dispositions"”. The Times. 16 June 1942. 4.

49 Military correspondent. "Rommel's primary aim attempt to overwhelm defence line". The Times. 16 June 1942. 4.

50 Ibid.

$51 \quad$ Special correspondent. "Tobruk stands by for siege”. Daily Mail. 19 June 1942. 1.

52 Ibid.

53 The decision to hold Tobruk, due to pressure from Churchill, was in fact made at the eleventh hour and went against the British policy of not allowing Tobruk to be invested for a second time.

54 Military correspondent. "Decision to hold Tobruk base denied to Axis". The Times. 20 June 1942. 4.

55 Reuter. "Frontier escarpment in Allied hands". The Times. 20 June 1942. 4.

56 N Orpen. South African Forces World War II: Victory in Italy. Cape Town: Purnell, 1975, 302-303.

57 SAPA. "Eastward advance of Axis stopped". Pretoria News. 20 June 1942. 1.

58 SAPA. "Springboks based on Tobruk harass Axis supply lines". Rand Daily Mail. 20 June 1942. 1.

59 SAPA. "General Smuts takes salute: Union proud of her soldiers". Pretoria News. 20 June 1942. 5.

60 NAP, JSP Box 137, f.132, Smuts to Auchinleck, Smuts encourages Auchinleck to hold Tobruk, 18 June 1942. Smuts had in fact encouraged Auchinleck to hold Tobruk.

61 J McClurg. "The Afrikaans press: From lapdog to watchdog?" Ecquid Novi: African Journalism Studies. 8/1. 1987. 55; SAPA. “Agste leer in twee gesny, sê Duitsers”. Transvaler. 19 June 1942. 1.

62 Agar-Hamilton \& Turner op. cit., pp. 100-101.

63 Interview with Clive Luyt, 27 August 2010, Cape Town.

64 Interview with Michael de Lisle, 4 June 2010, Cape Town.

65 Interview with William (Bill) Hindshaw, 19 March 2010, Johannesburg.

66 Correspondent. "'Soothing syrup' ...” op. cit., p. 3.

67 SAPA. "Springboks cool courage thwarted fierce Axis attacks". Rand Daily Mail. 20 June 1942. 1.

68 UWHS, DOCD, UWHS - Civil, Box 363, File PMH62C, Reports of South African Officers, Interview with Brigadier HB Klopper (Notes on Major Turner's interview), 6 May 1946.

69 The UWHS produced a trilogy which covered the Fall of Tobruk, the battle of Sidi Rezegh when the South African $5^{\text {th }}$ Brigade was annihilated on 23 November 1941 and South Africa's naval war. The premature closure of the UWHS in 1962 left a gaping hole in South Africa's military historiography. The other two books on the official history were JAI Agar-Hamilton \& LCF Turner. The Sidi Rezegh battles, 1941. Cape Town: Oxford, 1957, and L Turner, H Gordon-Cumming \& J Betzler. War in the southern oceans 19391945. Cape Town: Oxford University Press, 1961.

70 A Stewart. "The Klopper Affair: Anglo-South African relations and the surrender of the Tobruk garrison". Twentieth Century British History 17/4. 2006. 517, 533.

71 M Hastings. Finest years: Churchill as Warlord 1940-45. London: Harper Press, 2009, 298, 302. The fall of Tobruk was preceded by the fall of Singapore to the Japanese Army on 15 February 1942, and prior to that was the evacuation of Greece, Crete, Dunkirk and Narvik in Norway.

72 Mackay op. cit., p. 94.

73 Hastings op. cit., p. 302.

74 A Heckstall-Smith. Tobruk: The story of a siege. Essex: Anthony Blond, 1959. The author in his book draws unfair comparisons between the two sieges and accuses without substantial evidence that the South African commanders were drunk during the siege.

75 Correspondent. "Fall of Tobruk Unexpected". The Times. 2 July 1942. 1

76 Correspondent. "Critic's day in Parliament". The Times. 2 July 1942. 4.

77 In many ways, 1942 represented the zenith of German military might and the height of German territorial expansion achieved via a string of impressive victories on the Eastern Front and in North Africa. Robert Citino discusses this brilliantly in RM Citino. Death of the Wermacht: The German campaigns of 1942. Kansas: University Press of Kansas, 2007.

78 M Gilbert. Road to victory: Winston S. Churchill 1941-1945. London: Heinemann, 1986, 128.

79 D Todman \& A Danchev (eds). War diaries 1939-1945: Field Marshal Lord Alanbrooke. Los Angeles, CA: University of California, 2001, 269.

80 FL Monama. "Wartime propaganda in the Union of South Africa, 1939-1945". Unpublished DPhil thesis, Stellenbosch University, Stellenbosch, 2013, 142.

81 Churchill offered his condolences on the loss of the $2^{\text {nd }}$ Division to Smuts on 4 July 1942. NAP, JSP Box 95-1, f.119, Churchill to Smuts, Churchill debriefs Smuts on meeting with Roosevelt, 4 July 1942. In a follow-up letter on 6 July, Smuts reaffirmed his confidence in Churchill and final victory. NAP, JSP Box 95-1, f.120, Smuts to Churchill, Smuts expresses confidence in final victory, 6 July 1942.

82 J.L. Scoullar, Battle for Egypt : The Summer of 1942, ed. by H. Kippenberger. Wellington: Historical Publications Branch, 1955, pp. 1,2. 
83 JL Scoullar. Battle for Egypt, 5.

84 Ibid.

85 AM Grundlingh. "The King's Afrikaners? Enlistment and ethnic identity in the Union of South Africa's Defence Force during the Second World War, 1939-45". Journal of African History 40. 1999. 354. Of the 10 former POWs interviewed, two did not voice any specific opinion on Klopper. Of the remaining eight men, four expressed negative views and four expressed positive views. The negative views ranged from describing him as inexperienced, considering him as a man of no consequence in the events at Tobruk and blaming him for giving orders that none of the men were to try and escape.

Military Correspondent. "British losses in Armour Rommel's tactical superiority use of dive bombers". The Times. 22 June 1942. 4.

87 Correspondent. "Tobruk and Bardia are lost". Daily Mail. 22 June 1942. 1.

88 South Africa with the disaster at Sidi Rezegh in November 1941 and the surrender of Tobruk had lost a total of three brigades. South Africa's land forces, for all intents and purposes, remained out of the war for a period of 18 months after First Alamein. Thereafter, the UDF struggled to deploy a single armoured division to Italy. Acute manpower shortages owed much to the losses at Tobruk, although other factors such as racial policy and political divisions also played a fundamental role. For a discussion on these other factors, see Agar-Hamilton \& Turner, The Sidi Rezegh Battles op. cit., pp. 84-85 and I Gleeson. The unknown force: Black, Indian and coloured soldiers through two world wars. Rivonia: Ashanti, 1994, 106.

J Fennel. “'Steel my soldier's hearts': El Alamein reappraised". Journal of Military and Strategic Studies 14/1. 2011. 9. South African morale was "defective in that there is a large wastage of manpower owing to neurotic illness", and the various ways in which men got "themselves out of the fighting line, due to a loss of will to fight". R Crisp. Brazen chariots. London: Frederick Muller, 1959, 143.

Orpen op. cit., p. 459.

92 J Bourhill. Come back to Portofino. Johannesburg: 30 Degrees South, 2011, 31. C Birkby. The saga of the Transvaal Scottish Regiment 1932-1950. Cape Town: Hodder and Stoughton, 1950, 629.

93 JC Smuts. "Elections 1943", Memorandum Smuts to Churchill January 1943, National Archives Pretoria, Jan Smuts Collection Box 95-1 (152), 1943. Smuts was reluctant to become a 'second Ireland' due to South Africa's strategic importance to the Allied cause.

Stewart op. cit., p. 517.

Ibid., pp. 532-533.

DOCD, CGS WAR 47 File 12/6 Theron to van Ryneveld, Impact of Tobruk surrender, 1942.

97 Correspondent. "Lessons of Libyan campaign: British inferiority in hitting power". The Times. 23 June 1942. 4.

98 C Alexander. "Our Army was not rightly handled". Daily Mail. 23 June 1942. 2.

99 Ibid.

100 Ibid.

101 SAPA. "General Smuts on fall of Tobruk". Pretoria News. 22 June 1942. 1.

102 Grundlingh op. cit., pp. 354-359.

103 United Press War Correspondent. "Rommel nou voor poorte van Egipte". Die Vaderland. 22 June 1942. 1.

104 Own correspondent. "Skielike oorgawe van Tobruk nie verwag". Die Burger. 24 Junie 1942. 4.

105 Reuters. "Faulty leadership caused disaster". Daily Mail. 23 June 1942. 4.

106 Ibid.

107 P Fussel. The Great War and modern memory. New York, NY: Sterling, 2009, 218.

108 A Clifford. "Rommel swings into battle". Daily Mail. 15 June 1942. 1.

109 FJW Geldenhuis. A soldier's scrapbook. Unpublished memoirs, 90.

110 Correspondent. "Critic's day ... op. cit.

111 The motion was defeated by a vote of 476 votes to 25 . P Norton. "Winning the war but losing the peace: The British House of Commons during the Second World War". The Journal of Legislative Studies 4/3. 1998. 42.

112 D Berntsen \& DC Rubin. "Flashbulb memories and posttraumatic stress reactions across the life span: Agerelated effects of the German occupation of Denmark during World War II". Psychology and Aging 21/1. 2006. 129.

113 Brokensha op. cit., p. 83.

114 Gilbert op. cit., pp. 203-204.

115 Both Beukes and Oosthuizen blamed the British, while Brokensha, Van Alphen Stahl and Luyt believed they had insufficient materiel.

116 Interview with Wessel Oosthuizen, 4 December 2010, Hartenbos.

117 Klopper op. cit., p. 62.

118 Rosmarin op. cit., p. 17. 
Interview with Clive Luyt, 19 May 2010, Cape Town.

120 Interview with Michael de Lisle, 4 June 2010, Cape Town; interview with Fred van Alphen Stahl, 15 June 2010, Cape Town.

121 Interview with Fred van Alphen Stahl, 15 June 2010, Cape Town.

122 R Woods. Night train to Innsbruck: A commando's escape to freedom. London: William Kimber, 1983.

123 Quoted in M Leigh. Captives courageous. Rivonia: Ashanti, 1992, 3.

124 Brokensha op. cit., pp. 100-101.

125 Interview with David Brokensha, 10 September 2010, Fish Hoek.

126 Interview with Bernard Schwikkard, 17 March 2010, Johannesburg.

127 DOCD, CGS War, Box 47, Radio Zeesen transcript. Pretoria: Department of Defence Documentation Centre, 1942, 22.

128 C Marx. Oxwagon Sentinal: Radical Afrikaner nationalism and the history of the Ossewa Brandwag. Essen: LIT Verlag, 2008, 518. Radio Zeesen was a German broadcasting station operating from Germany that recruited a number of South African Afrikaners who edited and broadcast, among other topics, pro-German and anti-Smuts propaganda.

129 DOCD, CGS War, Box 47, File 4038, 1942, Bastin to van Ryneveld, In defence of Klopper's honour, 1942.

130 Gilbert op. cit.

131 V Peniakoff. Private army. London: Jonathan Cape, 1950, 393, 394.

132 Ibid.

133 MI9 was a secret branch of Military Intelligence during World War Two. MI9 instructed POW to remain in their camps following the Armistice agreement. Gilbert op. cit., p. 283.

- 1945: 283.

134 P Schamberger. Interlude in Switzerland: The story of the South African refugee-soldiers in the Alps during the Second World War. Parkhurst: Maus, 2001, 11-16; R Lamb. War in Italy 1943-1945: A brutal story. London: De Capo Press, 1993, 161-163.

135 B Nasson. South Africa at War 1939-1945. Auckland Park: Jacana Media, 2012, 14. 